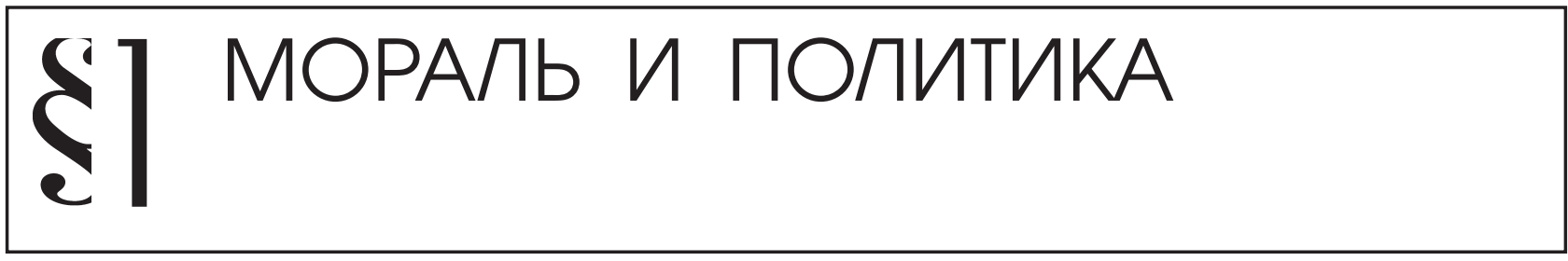

Барташевич C.B.

\title{
КАТЕГОРИЯ СВОБОДЫ В НАЛОГОВЫХ ПРАВООТНОШЕНИЯХ: ФИЛОСОФСКИЕ ПРЕДПОСЫЛКИ РЕШЕНИЯ ПРОБЛЕМЫ
}

\begin{abstract}
Аннотация: Статья представляет собой попытку абстрактно-теоретического осмысления проблем реализации идеи свободы в налоговом праве, основанной на синкретичности правовых принципов всеобщего формального равенства и справедливости, механизм практического воплощения которых испытывает явный кризис. В этой связи проводится критический анализ состояния российской налоговой политики и практики, широко использующей этические нормы, подменяющие собой правовую форму решении фискальных задач. Обосновывается роль как правовой науки, так и философского знания в деле поиска оптимального соотношения частных и публичных имущественных интересов и, как следствие, в устранении неопределенности грании свободы субъектов налоговых правоотношений.

Review: The article includes an attempt of an abstract-theoretical analysis of the problems regarding implementation of the idea of freedom in tax law, as based upon the syncretical character of legal principles of general formal equality and justice, since from the practical point of view their implementation is currently undergoing a crisis. Due to the above-mentioned issues, the author provides critical analysis of the situation in the modern Russian tax policy and practice, where ethical norms are used to substitute for the legal forms for achieving fiscal goals. The author stresses out the roles of legal science and philosophical knowledge in searching for the optimum correlation of public and private proprietary interests, which should consequently allow to eliminate vagueness of the limits to the freedom of subjects of tax relations.
\end{abstract}

Ключевые слова: Юриспрудениия, налог, право, свобода, воля, добросовестность, разумность, злоупотребление, нравственность, рецепция

Keywords: jurisprudence, tax, law, freedom, will, good-faith, reasonability, abuse, morals, reception.

\section{К постановке вопроса}

На современном этапе исторического развития общества и государства идеи свободы как никогда ассоциируются с «болевой точкой» налоговых правоотношений. Сегодня уже никого не удивить жесткими и нетерпимыми описаниями сложившейся ситуации, иногда именуемой даже «налоговым террором». ${ }^{1}$ Причин тому множество: от несовершенства действующего законодательства до полярности частных и публичных интересов. Существуют и объективные факторы, связанные с не поддающимся учету многообразием

\footnotetext{
1 Запольский С. В. Дискуссионные вопросы теории финансового права: монография / С. В. Запольский. - М.: Эксмо, 2008. C. 126 .
}

поведенческих вариаций в процессе реализации субъектами налогового права и, прежде всего, налогоплательщиками предоставленной им свободы выбора форм и методов хозяйствования.

Однако корень проблемы видится в другом. Как в обыденно-бытовом, так и в научно-теоретическом представлении вся проблематика свободы сводится к поиску оптимального соотношения допустимых и неприемлемых деяний. Российская налоговая система характеризуется крайней рассогласованностью правовых связей, призванных обеспечить единообразное понимание критериев дозволенного и недопустимого поведения субъектов налогового права, что выражается в постоянном противоборстве представлений двух антагонистичных сторон о сущих и должных пределах осуществления прав и защиты интересов каждой из них. 
Несмотря на внешнюю простоту постановки вопроса, его существо отнюдь не банально, не предлагает единой универсальной конструкции для решения поставленной задачи. Еще Ш.-Л. Монтескье писал: «Нет слова, которое получило бы столько разнообразных значений и производило бы столь различное впечатление на умы, как слово «свобода». ${ }^{2}$ В этом заключается диалектический характер вопроса. Как показывает практика, призываемые к разрешению публично-правовых конфликтов в обществе социальные регуляторы, инструментарием которых являются неправовые категории добра и зла, совести и разума, приводят лишь к новому витку эскалации проблем, связанных с эгоистичным пониманием, как самой свободы, так и способов ее реализации каждым из участников налоговых правоотношений. Философии же можно отвести роль того связующего звена, которое, храня в себе знания о подлинном предназначении права, его онтологической сущности, привнесет в правовую науку, в частности - в налоговое право, осознанную необходимость принимать в качестве отправной точки правотворческой и правоприменительной деятельности не только интересы государства как властного субъекта, но и интересы частных лиц как хозяйствующих субъектов.

В науке право характеризуется как многозначное, имеющее сложную структуру и разностороннее содержание явление. Понимание роли и места правовой составляющей в феномене свободы приходит уже при обращении к самому понятию и сущности права, играющего роль неотъемлемой части человеческого бытия и традиционно рассматриваемого как мера, масштаб свободы и поведения человека. Так, французская Декларация прав человека и гражданина 1789 г. ${ }^{3}$ провозгласила: «Люди рождаются и остаются свободными и равными в правах... Свобода состоит в возможности делать все, что не наносит вреда другому... осуществление естественных прав каждого человека ограничено лишь теми пределами, которые обеспечивают другим членам общества пользование теми же правами... Пределы эти могут быть определены только законом». Как видим, на первый план выдвигается идея свободы. И в этом смысле право, формально воплощенное в законе, становится одним из атрибутивных признаков свободной личности.

\footnotetext{
${ }^{2}$ Монтескье Ш. Л. Избранные произведения / Пер. А. Г. Горнфельда, М. М. Ковалевского. - М.: Госполитиздат, 1955. С. 288.

${ }^{3}$ Déclaration des Droits de l'Homme et du Citoyen.
}

Действительно, любая система правового регулирования, прежде всего, определяет пределы разрешенной деятельности участников общественных отношений. Целям обеспечения возможностей такой деятельности для одних всегда служит веление должного поведения для других. Иными словами, праву придается значение адекватной формы существования свободы, способной определять ее внешние границы через совокупность взаимовлияющих предписаний и дозволений.

В то же время, понимание права исключительно как масштаба свободы явно неполноценно. Более правильно с точки зрения фундаментального социального предназначения права говорить о справедливом масштабе свободы равных, хотя бы по формальным признакам, субъектов, что гарантирует последним не только возможность самоопределения, но и защиту от результатов самореализации себе подобных.

О внутренней тождественности всех современных подходов к понятию права, различающихся лишь внешней формой интерпретации принципа формально-юридического равенства, которое, в свою очередь, невозможно без правовой свободы, говорит в своих работах В. С. Нерсесянц. ${ }^{4}$ Ученым очень точно представлен истинный глубинный смысл феномена права вне привязки к отраслевым и иным конкретизирующим проявлениям, и с ним нельзя не согласиться. Единственной сущностью права является всеобщее формальное равенство, преследующее цель достижения необходимой и достаточной свободы в общественных отношениях.

Отраслевые правовые общности не лишены того же объективно-сущностного содержания, основанного на идее всеобщей и равной свободы, что и право в целом. Финансово-правовая сфера здесь не является исключением. Несмотря на то, что налоговое право, впитав в себя все основные черты административно-правового метода, построено по модели властного подчинения одного субъекта другому, не следует говорить об отсутствии свободы как таковой в налоговых правоотношениях. Безусловно, в фискальной сфере приоритет отдается публичным интересам перед частными, и это вполне естественно. Однако публично-правовая природа определяет лишь масштаб и объем свободы, в определенной степени ограничивая круг

\footnotetext{
${ }^{4}$ См.: Нерсесяни В. С. Право - математика свободы. Опыт прошлого и перспективы / В. С. Нерсесянц. - М.: Юристъ,
} 1996. C. $18-19$. 


\section{Политика и общество 8 (104) • 2013}

дозволенного для частных субъектов. Кроме того, всеобщая равная мера позволяет ограничить пределы деятельности носителя власти, не допуская умаления пусть даже малой части свободы финансово-обязанных лиц. В этом смысле особую ценность представляет высказывание Д. В. Винницкого о том, что налоговому праву свойственны не отношения полного подчинения одного участника воле и усмотрению другого, а отношения, базирующиеся на прямом подчинении налоговым нормам, регламентирующим деятельность всех участвующих лиц. ${ }^{5}$ Отрицание идеи свободы в налоговых правоотношениях означало бы возможность осуществления ничем не урегулированного воздействия одних на поведение других, оправдывая всякий произвол.

В то же время, свобода частного субъекта в налоговом праве не безгранична и не самодостаточна, она есть следствие официального признания возможности выбора путей постижения имплицированной налоговым правом аксиологии. Так, субъективные права как мера возможного поведения фискально-обязанного лица, заключающая в себе потенциал легального избежания налогообложения, зачастую производно от юридической обязанности уплаты налога и имеет своей главной целью обеспечение исполнения последней. Подобные дозволения устанавливаются лишь в той части, которая способствует государству наиболее эффективно реализовать свою фискальную функцию, а потому их следует рассматривать как составляющую часть механизма юридического обеспечения наполнения казны. В итоге мера правовой свободы проецируется не столько на ее номинального обладателя, сколько на властного субъекта, в чьем лице представлен публичный интерес.

\section{Сущность и значение категории свободы в налоговом праве}

Свобода есть возможность проявления субъектом своей воли в условиях осознания законов развития природы и общества. В общеупотребительном смысле под свободой также понимается независимость, отсутствие каких-либо стеснений и ограничений, связывающих общественно-политическую жизнь и деятельность какого-нибудь класса, всего общества или его членов. Как видим, семиотически понятию «свобода»

\footnotetext{
${ }^{5}$ См.: Винницкий Д. В. Субъекты налогового права / Д. В. Вин-
} ницкий. - М.: Норма, 2000. С. 159. даются весьма обширные определения вне сращения с особенностями его отраслевой принадлежности какой-либо отрасли научного знания.

В общефилософской интерпретации под свободой принято понимать состояние самоопределения субъекта, его способность действовать в соответствии с собственными интересами, целями и исходя из познанной объективной необходимости. ${ }^{6}$ Иными, самыми общими словами свободу можно описать как наличие реальной возможности изменения обычного хода вещей, выбора вариантов завершения события. Отсутствие таковых равносильно отсутствию свободы.

Однако применительно к налоговым правоотношениям подобная трактовка свободы, если и может быть принята, то со значительными ограничениями. Система единых формализованных правил поведения не дает и не должна давать повод чувствовать себя свободным от любых ограничений, в чем бы они не выражались. Философия как аксиому признает бессмысленность абсолютной свободы от общественных условий. ${ }^{7}$ В праве же свобода имплицирует меру возможного поведения лица, обычно закрепленную в нормативно-правовых актах, тем самым, элиминируя из цивилизованного понимания свободы вседозволенность, по сути, парализующую посредством элементов случайности и неопределенности бытия свободную человеческую сущность. Правовая свобода предполагает существование субъективного права, имеющего конкретное юридическое содержание, гарантии его осуществления и соответствующую корреспондирующую обязанность. И здесь возникает проблема, заключающаяся в том, что свобода не обладает такой же степенью конкретизации как субъективное право, что особенно заметно в налоговом праве.

Специфика понимания свободы в налоговом праве должна исходить из природы публично-правовых отношений. Так, самоопределению каждого налогоплательщика противостоит всеобщий интерес, консолидированный в лице государства. В научной литературе не без повода отождествляют налогообложение как частный случай публичных финансов со сферой стол-

\footnotetext{
${ }^{6}$ См.: Черненко А. К. Взаимодействие права и свободы: проблемы интеграции // Гуманитарные науки в Сибири. -2000. - №1. С. 85-91.

${ }^{7}$ См.: Чернобель Г. Т. Право как мера социального блага // Журнал российского права. - 2006. - №6. С. 83-95; Орлова О. В. Правовая свобода личности в гражданском обществе // Журнал российского права. - 2007. - №5. С. 76-83.
} 
кновения различных, подчас противоречивых и разнонаправленных интересов, включая государственные, групповые и индивидуальные. ${ }^{8}$ Ввиду того, что регулируемые публичным правом отношения образуют базис для существования государственно-организованного социума, свобода действий частных субъектов должна преследовать, в первую очередь, не индивидуальные потребности, а общее благо. По этой же причине она не может быть абсолютной и всеобъемлющей. Кроме того, в отличие от диспозитивной сферы, возникновение налоговых правоотношений непосредственно не зависит от волеизъявления их субъектов, внутреннее отношение субъекта к налогово-правовому предписанию не способно оказать на него преобразующее воздействие, изменить ход его реализации по своему усмотрению, за исключением редких случаев, прямо предусмотренных законом.

Поскольку свобода вовлеченности в налоговые правоотношения априори отсутствует, абсурдно было бы говорить о наделении их участников свободой и возможностью самореализации, которая, как уже было сказано выше, не имеет телеологической самостоятельности. При этом данное утверждение справедливо как для налогоплательщиков, так и для налоговых органов, олицетворяющих собой государство. Произвольное ограничение свободы налогоплательщиков, с одной стороны, автоматически ведет к произвольному установлению свободы, а с другой - жесткая регламентация поведения до степени низведения субъекта в ранг бессознательного, технического исполнителя наносит ущерб, как нормальному хозяйственному обороту, так и налоговой системе, ведь благодаря принципам свободы общественные отношения приобретают способность адаптироваться к динамике объективной реальности. Допустимым является только то право выбора, которое изначально и в целях достижения того же общего блага предоставлено в нормативном порядке или пусть даже формально не предоставлено, но предполагается принципами и самим смыслом права. Ценность свободы в налогово-правовых отношениях состоит в том, что предоставляет возможность целенаправленного и планомерного освоения благ, содержащихся в законодательстве о налогах и сборах. При этом принцип свободы неизбежно возлагает на фискально-обязанное лицо, само-

\footnotetext{
${ }^{8}$ См.: Козырин А. Н. Публичные финансы и финансовое право // Финансовое право России: актуальные проблемы / Под ред. А. А. Ялбулганова. - М.: Academia, 2007. С. 8.
}

стоятельно выбирающего юридические конструкции осуществления хозяйственной деятельности на основе оценки их утилитарности и правовой идентичности, и бремя ответственности за сделанный выбор или принятое решение.

Понятие свободы как общефилософской категории тесно связано с другой категорией, а именно необходимостью, в чем выражается взаимоотношение деятельности участников правоотношений и объективных законов правового бытия. По общему правилу, необходимость свойственна таким процессам и событиям, результаты которых закономерно подготовлены предшествующим ходом их развития и характеризуются неизбежностью, то есть не подчинены стохастическим законам. На разных этапах развития научного знания подходы к соотношению свободы и необходимости существенно рознились ${ }^{9}$ и современное научнодиалектическое объяснение свободы и необходимости основано на признании их органической взаимосвязанности. Именно наличие необходимости делает свободу возможной. Презюмируется, что субъект не может избавиться от действия ни естественной, ни общественной необходимости, обладая при этом возможностью выбора между названными детерминантами, а это нереализуемо без знания имеющихся вариантов поведения. Впервые же попытку преодолеть метафизическую полярность рассматриваемых понятий, как видится, предпринял Б. Спиноза, определив свободу как осознанную необходимость.

Поскольку необходимость в налоговых правоотношениях существует в форме позитивных правовых установлений и исключительно благодаря им, следует признать верной теоретическую конструкцию, где объективная необходимость выступает в роли первичной категории, а свободная воля вторична по отноше-

\footnotetext{
${ }^{9}$ В частности, приверженцы идеалистических направлений в философии рассматривали свободу и необходимость как взаимоисключающие понятия, поскольку свобода, будучи недетерминированной внешними условиями, дает возможность поступать согласно собственному волеизъявлению, а детерминированная необходимость, снимая всяческую ответственность с человека за его действия (бездействие), не имеет подобной ценности. Напротив, материалисты в большинстве своем не придают свободе существенного значения, поскольку поступки человека в любом случае предопределены не зависящими от него обстоятельствами, что особенно явно прослеживается в метафизической философии механистического детерминизма, абсолютизирующей объективную категорию необходимости в общественных отношениях до степени фатализма.
} 


\section{Политика и общество 8 (104) • 2013}

нию к окружающей необходимости и производна от нее. Более того, право, в том числе налоговое, являясь адекватной формой существования свободы, консолидирует ее с необходимостью в единое гармоничное целое. Налоговое право предоставляет свободу участникам регулируемых отношений в той мере, в какой последними воспринято его внутреннее содержание. Вне субъективного освоения необходимости не представляется возможным вычленить свободу из объединяющего ее с названной необходимостью целого, увидеть масштабы потенциальной свободы, а значит неосознанная необходимость не может служить источником свободы. Таким образом, степень свободы и осознанности деятельности субъекта прямо пропорциональна величине постижения субъектом правового бытия с его ограничениями и дозволениями. В этом проявляется столь важная эпистемологическая сущность налогового права, посредством которой становятся очевидными исходные позиции реализации фискально-обязанными лицами своей свободы в рамках императивных налогово-правовых отношений.

Свобода как в общефилософском, так и в правовом значении непосредственно коррелирует с понятием «воля». По общему правилу, воля характеризуется как свойство личности, определяющее ее сознательную целеустремленность на выполнение конкретных действий (бездействия). Деятельность субъектов права всегда осуществляется либо в соответствии с правовыми нормами, либо с их нарушением, что есть результат волевого акта субъекта. Следовательно, воля в налоговом праве является категорией свободной, внутренне индетерминированной и в то же время разумной, определяющей направления поведения лица, его стремление к праву или к произволу. Этот волевой момент неотъемлемо присутствует в процессе освоения пределов свободы участниками налоговых правоотношений.

Свободе воли присущи все основные атрибуты собственно свободы. Общую квинтэссенцию проблемы свободы воли составляет следующая презумпция: если поведение субъекта всецело зависит от него самого, то и бремя ответственности за последствия такого поведения несет сам субъект. Философским знанием за все время своего существования выработано два противоположных подхода, а именно - положительный и отрицательный, к решению данной проблемы, ${ }^{10}$

${ }^{10}$ В качестве положительного подхода принято называть ин-
детерминизм, признающий волю полностью свободной, не
испытывающей на себе причинного влияния. Отрицатель- но уже сегодня большинство авторов соглашаются с тем, что ни одна из указанных полярностей, преподнесенная в ее крайней форме, не оставляет места истинной свободе. ${ }^{11}$ Однако применительно к проблеме свободы в ее налогово-правовом аспекте гораздо большую ценность имеет другая сторона вопроса: насколько свободен субъект налогово-правовых отношений, и где находятся, а главное, как познать те правовые ограничения и дозволения, которые этот субъект не должен преступать?

Источником и одновременно объектом волевой деятельности налогоплательщика является экономико-правовое бытие, включающее налогово-правовые предписания, сложившиеся в государстве экономические условия, практику налоговых и иных фискальных органов. Субъект познает отдельные элементы налогово-правового бытия, экстраполирует их на конкретную ситуацию, после чего своими действиями (бездействием) преобразует налогово-правовое бытие для достижения поставленных целей. При этом субъект может или руководствоваться осознанными правовыми предписаниями, или сознательно их отвергать. Соотнесение объективных условий, онтологически диктуемых налоговым законодательством, с внутренними потребностями, желаниями и эгоистическими интересами предоставляет субъекту возможность выбора одного из вариантов поведения, принятия решения, определяющего смысл и назначение последующего волевого акта. Именно на основании оценки налогоплательщиком собственного поступка, внутреннего отношения к его последствиям должен решаться вопрос о степени налогово-правовой свободы. Так, одного только желания абстрактного добра Г. Гегель считал достаточным для признания поступка в целом добрым, при этом каждый субъект свободен наполнить абстрактное добро содержанием или, в чем нет никакой разницы, подвести его под некоторое всеобщее. ${ }^{12}$ Иными словами, веление блага свидетельствует о добросовестном прило-

ный подход, не признающий обособленность воли от объективных движущих сил окружающего мира и общественного устройства, а потому отвергающий ее свободу, сложился в рамках детерминизма

${ }^{11}$ См.: Микешина Л. А. Философия науки. Эпистемология. Методология. Культура / Л. А. Микешина. - М.: Издательский дом Международного университета в Москве, 2006. C. 155 .

${ }^{12}$ См.: Гегель Г. В. Ф. Философия права / Пер. Б. Г. Столпнера, М. И. Левиной. - М.: Мысль, 1990. С. 187. 
жении свободы к той или иной предметной области. Лицо, умышленно или необдуманно преступающее правовые запреты и ограничения, установленные в интересах публичного образования, руководствуясь лишь личными побуждениями, не может считаться свободным, поскольку желаемый результат в идеале будет нивелирован неблагоприятными последствиями властного принуждения - правовыми санкциями. Напротив, свободным следует признать того, кто способен сознательно принять оптимальное или даже единственно верное решение из множества возможных, исходя из действующего правопорядка, налоговой системы государства и иных строгих реалий налогово-правового бытия.

Приведенная логика вполне естественно генерирует материалистическое понимание воли, о свободе которой еще Ф. Энгельс писал как о «способности принимать решения со знанием дела». ${ }^{13}$ Однако в данном определении усматривается на первый взгляд вовсе незаметное противоречие, порождаемое сочетанием утверждений о невозможности обретения субъектом независимости от объективных законов общества и об обратной детерминации обстоятельств бытия целенаправленной преобразующей деятельностью субъекта. Тем самым, возникает не получившая до настоящего момента должного разрешения дилемма между свободой воли и лапласовским детерминизмом.

В контексте налоговых правоотношений проблема совместимости доминантных императивных и акцессорных диспозитивных начал усугубляется вполне ожидаемым вопросом: есть ли место воле в публично-правовых отношениях вообще? Исходя из изложенного, представляется, что в рамках налогово-правовых отношений как одного из видов публичных правоотношений более уместно говорить о свободе выбора, нежели о свободе воли. При этом под свободой выбора следует понимать не эфемерную обсервацию поведения налогоплательщика от явлений налогово-правового бытия, что недопустимо в принципе, а возможность использования указанных явлений тем или иным избранным на основе познавательной, юридико-аналитической деятельности способом в собственных интересах, для достижения самостоятельно поставленных налогоплательщиком экономических целей.

\footnotetext{
${ }^{13}$ Фарбер И. Е. О классово-волевом характере права // Правоведение. - 1957. - №1. С. 32-41.
}

\section{Классификация свободы и плюрализм ее форм}

В философской литературе справедливо различают свободу внутреннюю и внешнюю, ${ }^{14}$ при этом именно последней, как правило, придается правовая форма бытия, поскольку, по общему правилу, право безразлично к внутренним умонастроениям подчиненных ему субъектов. В отличие от бесконечной свободы внутреннего духа, только внешнее выражение свободы, материальное воплощение сознательной деятельности лица подлежит правовой регламентации, в том числе путем установления пределов названной свободы, гарантий возможностей ее реального осуществления и способов защиты от иных внешних посягательств. Масштаб внешней свободы зависит, главным образом, от объективной величины интернированных законом в строго определенные границы внутренних и внешних возможностей выбора юридически значимых целей и средств их осуществления.

Исходя из изложенного, становится очевидным, что философские проблемы внутренней свободы не представляют интереса для налогового права. Однако это отнюдь не означает, что при установлении масштаба внешней свободы законодатель довольствуется исключительно внешними действиями (бездействием), его также интересуют внутренние побуждения и настроения субъекта, но лишь в той мере, в какой они повлияли на воплощение деяния в жизнь. Внешнюю свободу в большой степени характеризуют экономические интересы субъектов и, следовательно, то, какими методами эти интересы реализуются. При этом исходным началом понимания степени свободы должна быть оценка, желательно регламентированная законом, руководящего субъективного интереса на предмет его правомерности или противоправности. Поскольку участник правоотношений до момента совершения поведенческого акта никак не обозначает своего участия в них, а соотнесение масштабов закрепленной за субъектом свободы с реальными границами его практической деятельности вне эмпирической составляющей не имеет смысла, можно с уверенностью говорить, что основное содержание внутренней свободы составляет свобода и автономия воли лица, а содержание свободы внешней - свобода его действий (бездействия) или, иными словами, волеизъявления.

\footnotetext{
${ }^{14}$ См.: Кузубова А. Ю., Сафронова Е. В. Тема прав и свобод человека в философской концепции К. Н. Леонтьева // История государства и права. - 2006. - №12. С. 33-35.
} 


\section{Политика и общество 8 (104) • 2013}

В контексте свободы выбора выделяют положительную и отрицательную свободу. ${ }^{15}$ Для современного общества данная градация не просто имеет большое значение, но и несет собой весомые философские предпосылки к решению правовой проблемы соотношения дозволенного и недопустимого поведения налогоплательщиков в отсутствие четких законодательных установлений. В частности, идея положительной свободы как условие предоставления правовой защиты действиям (бездействию) фискально-обязанного лица, направленным на уменьшение налогового бремени, нашел свое отражение в правоприменительной доктрине деловой цели.

Суть отрицательной свободы заключается в стремлении субъекта избавиться от воздействующих на его бытие внешних сил, от порядка и необходимости как неотъемлемых составляющих объективной реальности. В налогово-правовых отношениях такая свобода выражается в действиях (бездействии) обязанного лица, направленных исключительно на избежание налогообложения и ни на что более. Очевидно, что такая свобода априори деструктивна. В свою очередь, реализуя положительную свободу, налогоплательщик через уменьшение налоговых обязательств желает достичь ранее отсутствовавших разумных хозяйственных результатов. По сути, положительная свобода направлена на эффективное преобразование неблагоприятных, чуждых субъекту обстоятельств в субъективно благоприятные явления. Снижение налоговых поступлений в бюджет в данном случае не является самоцелью, оно лишь параллельно сопутствует конкретным добросовестно совершаемым, экономически оправданным рыночной средой и разумной деловой целью хозяйственным операциям.

Н. А. Бердяев и С. Л. Франк осуждали отрицательную свободу, считая ее бессмысленной, внутренне пустой и ничего не дающей взамен, ${ }^{16}$ и, напротив, всяче-

\footnotetext{
15 Такой подход был разработан, прежде всего, представителями русской религиозной философии в целях определения онтологического основания свободы. Например, согласно Н. А. Бердяеву положительную свободу образуют созидательные желания человека посредством достижения состояния свободы приобрести что-либо, а под отрицательной свободой - стремления освободиться, избавиться от чего-либо.

${ }^{16}$ См.: Михайлов П. В. «Положительная» и «отрицательная» свобода в русской религиозной философии начала XX века // София: рукописный журнал Общества ревнителей русской философии. - 2001. - №3. URL: http://www.rustrana.ru/print. php?nid=13181.
}

ски поощряли ее антипода - положительную свободу. Однако в разумных пределах отрицательную свободу следует признать даже необходимой, поскольку стремление человека освободиться от устоявшихся, закоренелых норм может спровоцировать позитивный сдвиг в общественных отношениях и послужить интересам прогресса социальных институтов. И. Кант, например, полагал, что идущие вразрез со сложившейся детерминацией действия, порождаемые только индивидуальной волей, способны нарушить цепь предопределенных событий и вызвать к жизни новые причинно-следственные связи. В этом видится единственная точка соприкосновения положительной и отрицательной свободы, а также трансформации свободы из одной формы в другую. Поскольку та или иная форма бытия свободы в конечном итоге зависит от самостоятельного выбора субъекта и его осознанного решения, философская концепция, заимствованная у русских мыслителей начала XX века, может быть использована для выработки уже правовой концепции оценки правомерности поведения субъектов налоговых правоотношений. Таким образом, в основу законодательства о налогах и сборах должно быть положено строгое разграничение действий (бездействия), направленных на реализацию отрицательной и положительной свободы, правовое регулирование первых из которых осуществляется запретительными методами, а вторых - дозволительными.

\section{Рецепция неправовых категорий налоговым правом}

Поскольку любое проявление правового бытия всегда облечено в формальные рамки, то и налоговое право можно назвать формой существования свободы фискально-обязанных и уполномоченных лиц. В правовую форму, являющуюся той несущей конструкцией, которая определяет действительность и объективность свободы в любом ее цивилизованном проявлении, облекаются общественные отношения формально равных участников процесса налогообложения и взимания сборов, которые должны подчиняться, как уже было сказано выше, лишь общим правилам поведения.

По словам К. Н. Леонтьева, «форма есть деспотизм внутренней идеи, не дающий материи разбегаться». ${ }^{17}$

\footnotetext{
17 Леонтьев К. Н. Византизм и славянство // Россия глазами русского: Чаадаев, Леонтьев, Соловьев / Сост. А. Ф. Замалеев. - СПб. Наука, 1991. С. 185.
} 
Ретранслируя данное утверждение на финансово-правовые отношения, в том числе налоговые, можно сделать вывод о наличии объективной необходимости в установлении общей нормы, придающей общественным отношениям стабильность и определенность. В свою очередь, любые действия (бездействие), отвечающие интересам установления такой общей нормы должны быть признаны допустимыми.

В связи с многогранностью и межотраслевой принадлежностью категории свободы, которая не может не оказывать влияния на ее широкую интерпретацию в философии и правовой науке, попытки охарактеризовать и определить сущность свободы на формальном уровне зачастую сталкиваются с целым рядом сложностей, а то и вовсе заходят в тупик. В налоговом праве особая актуальность данной проблемы обуславливается значением имущественного благосостояния для осуществления предпринимательской деятельности в частности и гражданского оборота в целом, а также правовых гарантий его приобретения, сохранения и приумножения. Стремление участников налоговых правоотношений максимально полно реализовать свою свободу порождает несчетное разнообразие практических ситуаций, оценка которых с полярных позиций вполне естественно порождает конфликт частных и публичных интересов. Урегулировать всю совокупность проявлений налогово-правового бытия, в том числе опирающихся на принцип свободы хозяйствования, исключительно законодательными средствами, как показывает опыт, не всегда представляется возможным. П. В. Евдокимов, к примеру, видит причины тому в объективной неспособности законодателя предвидеть всевозможные варианты осуществления деятельности налогоплательщиков. ${ }^{18}$ Напротив, Е. А. Суханов поводом для выдвижения различных теорий, в том числе использующих инструментарий смежных, но все же чуждых налоговому праву областей знания, называет изменение экономического уклада в порядке закономерностей развития рынка. ${ }^{19}$ Другим же видится обратная закономерность, то есть активизация второстепенных

18 См.: Евдокимов П. В. Противодействие уклонению от уплаты налогов - современный взгляд на «старую» проблему // Финансовое право России: актуальные проблемы / Под ред. А. А. Ялбулганова.- М.: Academia, 2007. С. 171.

${ }^{19}$ См.: Суханов Е. А. Осторожно: гражданско-правовые конструкции // Законодательство. - 2003. - №9. С. 60-65. социальных регуляторов вследствие нестабильности правопорядка, отсутствия полноценного режима законности и ослабления действенности формально признанных норм права. ${ }^{20}$ Именно поэтому приходит осознание необходимости в выработке общей нормы, способной организовать функционирование фискальной сферы по единому и равному масштабу. В свою очередь, недостаточность одного только правового потенциала для решения поставленной задачи либо неумение его освоить заставляет общество обращаться к смежным отраслям знания, в том числе философии. При этом познание и освоение новых способов объяснения явлений, как правило, требует дополнительных интеллектуальных и временных ресурсов, параллельно создавая почву для новых ошибок и заблуждений.

Сегодня в российском законодательстве о налогах и сборах проблема свободы и, в частности, определения ее границ, установления пределов дозволенного поведения решается посредством внедрения в правовую сферу абстрактных общефилософских категорий, включая всем известные «добро», «зло», «совесть», «разумность» и иные. Первый же взгляд на данные понятия позволяет ощутить их морально-нравственную, но никак не правовую, природу, что в идеале должно вызывать скептическое отношение к удельному весу их ценностной и утилитарной нагрузки в массиве правил поведения, построенных и существующих по законам строгой формальной определенности. Однако чтобы понять сущностные силы, реципировавшие всегда считавшиеся чуждыми праву явления в правовую сферу, очертить границы их применения не только в налоговом праве, но и в праве вообще, обосновать перспективы их использования в налоговой практике, необходимо ответить на ряд ключевых вопросов. Действительно ли названные категории способны решить проблему свободы в налоговых правоотношениях? Или это только попытка хоть немного приблизиться к решению данной проблемы, порожденная безвыходностью ситуации?

Система публично-правового регулирования в отличие от тех же частных правовых общностей подчинена в большинстве своем строго формализованным установлениям императивного характера. Как отмечает А. Н. Козырин, «финансовые отношения могут

${ }^{20}$ См.: Бошно С. В. Доктринальные и другие нетрадиционные формы права // Журнал российского права. - 2003. - №1. C. 82-91. 


\section{Политика и общество 8 (104) • 2013}

существовать исключительно в форме правоотношений... Финансовые правоотношения представляют собой единственно возможную форму существования финансовых отношений в современно демократическом правовом государстве». ${ }^{21}$ Более того, юридическая наука стоит на позициях, согласно которым правовые предписания укореняются в социуме в тот момент, когда иных социальных регуляторов, в том числе норм морали и нравственности, становится явно недостаточно для поддержания жизнеспособности идей свободы, равенства и справедливости, а не наоборот. Несмотря на это, в современной налоговой практике очень часто оперируют откровенно навязывающими нравственную оценку поведения субъектов категориями добросовестности и недобросовестности. Вовлечение их в правоприменительный и затем научный оборот произошло, главным образом, посредством судебного санкционирования. При этом дать указанным понятиям четкое определение оказывается весьма затруднительным задачей.

\section{Добросовестность в философии и праве}

Лексическую структуру понятия «добросовестность» образует две самостоятельные, но в то же время не лишенные точек соприкосновения, морфемы, а именно «добро» и «совесть». Традиционно добро, равно как и его антипод - зло, упоминаются в качестве категорий этики и идей морали, выражающих в максимально абстрагированном виде эталон должного, к чему надлежит стремиться всему сущему, и, соответственно, верх недопустимого, отрицаемого самой человеческой природой. В философии добро называют высшим благом как конечной целью, а также восходящей к ней пирамидой промежуточных целей, моральная обязанность стремления к которой не вызывает сомнения, в свою очередь, зло является аксиологически противоположной целью. Оба понятия, с одной стороны, крайне антонимичны и отрицают друг друга, a, с другой, не исключают возможности совместного существования в объективной реальности. Дуалистический характер добра и зла проявляется в их мировоззренческой функции, благодаря которой формируется их восприятие как равновесных онтологических начал. В налоговых правоотношениях перманентное состояние конкуренции частных и публичных интересов по своей сути отражает процесс поиска субъектами нало-

\footnotetext{
${ }^{21}$ Козырин А. Н. Указ. соч. С. 7.
}

гового права доброго и злого, который был бы невозможен вне принадлежащей им свободы, в отсутствие возможности действенно выражать свое отношение к налогово-правовому бытию. Действие (бездействие), соотнесенное с моральными ценностями и идеалами, требующее иногда нетривиального выбора между благим и вредным, а также включающее в себя внутреннюю мотивацию, философией права воспринимается как поступок, через который внешне проявляется личность. ${ }^{22}$ Иными словами, противоборствующие проявления добра и зла в правовой сфере одновременно порождают необходимость выбора между ними и свободу изысканий направления и характера поведения, что в целом определяет как причину, так и следствие конфликтов, образуя своеобразный замкнутый круг. Таким образом, диалектика понятий добра и зла заключается в том, что бытие каждого из них носит не автономный, а коррелирующий характер.

На настоящий момент в европейской философской мысли преобладает взгляд на соотношение категорий добра и зла, согласно которому добро есть самостоятельное начало бытия, а зло - это лишь недостаток добра, оно субстанционально не укоренено. ${ }^{23}$ Следует признать данную точку зрения не лишенной рационального зерна, что находит свое подтверждение и в налоговых правоотношениях. Идеал должного принципиально недостижим, но при этом он дает стимул конструктивному развитию общественных отношений, прогрессу системы правового регулирования через чередование событий устранения уже имеющихся и выявления новых огрехов. Цель такого процесса видится в интенсификации созидающей функции добра, освоении ранее неизвестных экономико-правовых благ и подавлении разрушающей функции зла. Недобросовестная реализация меры возможного поведения, злоупотребление индивидуальной свободой есть не что иное, как упомянутый недостаток добра, элиминирование которого вменяется изыскиваемой в нравственных основах права общей норме.

Другая внеправовая категория, а именно совесть, являет чувство нравственной ответственности за свое поведение перед окружающими людьми, обществом и

${ }^{22}$ См.: Иванов И. С. О влиянии социально-философских и психологических учений на восприятие вины у налогоплательщиков // Российский следователь. - 2008. - №2. С. 32-36.

${ }^{23}$ См.: Левицкий С. А. Свобода и ответственность: «основы органического мировоззрения» и статьи о солидаризме / Сост. и коммент. В. В. Сапова. - М.: Посев, 2003. С. 156-157. 
собой. Совесть детерминирует умение самостоятельно формулировать собственные нравственные обязанности и осуществлять самоконтроль за исполнением долга, быть требовательным к себе, проводить оценку совершаемых поступков. Можно сказать, что совесть играет роль внутреннего источника рационального осознания нравственного значения действий (бездействия) лица. В философии совесть принято воспринимать как некое целостное образование духовной жизни человека в единстве ее интеллектуальных, нравственных и волевых составляющих, посредством которых она определяет способность личности осваивать выработанные людьми представления о ценностях, стремление направлять свои помыслы таким образом, чтобы при выборе между различными по ценности альтернативами предпочтение отдавалось бы более ценной. ${ }^{24}$

Попытку связать воедино понятия добра и совести предпринимал Г. Гегель. Философом справедливо отмечено, что добро обретает реальные черты лишь через его субъективное осознание, то есть через переживание совести как субъективной идеи. ${ }^{25} \mathrm{C}$ другой стороны, гегельянская концепция нравственности поступком, совершенным со злой совестью, считала тот, который совершен с субъективным осознанием его как злого, поскольку субъекту известно некое всеобщее и в сравнении его с противоборствующей волей данный субъект уверяется в нем как во зле. ${ }^{26} \mathrm{~B}$ такой трактовке совесть, помимо прочего, является катализатором процесса идентификации добра и зла в правовой действительности, методом иррационального познания должного в налогово-правовом бытии. Похожей точки зрения придерживался и экзистенциалист В. Франкл, дефинируя совесть в качестве органа, позволяющего в любой ситуации уловить истинный смысл. ${ }^{27}$ Б. Н. Чичерин, в свою очередь, называл совесть началом, которое определяет приложение единого отвлеченно-общего закона ко всему эмпирическому разнообразию жизни. Поскольку она дает беспристрастную оценку добра и зла в приложении к каждому деянию, постольку проясняет, что для человека является обязанностью

\footnotetext{
${ }^{24}$ См.: Назаретян А. П. Совесть в пространстве культурноисторического бытия (полемические заметки) // Общественные науки и современность. - 1994. - №5. С. 152-160.

${ }^{25}$ См.: Гегель Г. В. Ф. Лекции по философии и истории / Пер. Водена А. М. - СПб: Наука, 2000. С. 80-81, 213-214.

${ }^{26}$ См.: Савсерис C. В. Категория «недобросовестность» в налоговом праве / С. В. Савсерис. - М.: Статут, 2007. С. 10.

${ }^{27}$ См.: Иванов И. С. Указ. соч. С. 32-36.
}

в разнообразных бытийных ситуациях. Свойства совести составляют неотъемлемую принадлежность лица как нравственного существа, характеризуя собой явления его внутренней свободы и самоопределения. ${ }^{28}$ Следует также отметить, что в данном контексте гносеологической атрибутивности совесть отражает еще и требования разумности, которые с точки зрения философии права предполагают соответствие поведения индивида социальному опыту, осознанность и мотивированность его деяний. При этом исследователями специально подчеркивается, что в открытых системах, к числу которых, безусловно, следует отнести и фискальные правоотношения, наличествует много пробелов, и поэтому разум должен признаваться самостоятельным источником права. ${ }^{29}$

Выражая важное свойство соизмерять ожидаемое или свершенное с разделяемыми в социуме ценностями, а также самостоятельно одобрять или осуждать избранное направление деятельности по результатам ее нравственной оценки, понятие совести все же не несет никакой утилитарной нагрузки для проблемы эпистемологии правовой свободы. Совесть как внутренне присущий человеку духовный ориентир формируется параллельно с развитием личности, впитывая в себя множество сторонних факторов, в том числе воспитание, образование, отношение к религии, а потому критерии оценки моральности собственного поведения в одном социуме могут кардинально розниться. Уже сформировавшиеся моральные и этические принципы образуют когнитивный компонент совести. ${ }^{30}$ Кроме того, едва ли не каждому индивидууму в той или иной мере свойственно определенное сочувствие к самому себе. Данное утверждение справедливо и для организаций, поскольку самооценка поведения хозяйствующего субъекта опосредуется мыслительной деятельностью конкретного, так или иначе заинтересованного в плодах хозяйствования индивида. Как отмечается исследователями, делимитация дозволенного и запрещенного, отдаваемая на откуп совести, явствует из характерной неопределенности нравственных регуляторов, но она непростительна для норм права. ${ }^{31}$ Попытки ввести понятие «совесть» в правовую сферу не-

\footnotetext{
${ }^{28}$ См.: Чичерин Б. Н. Философия права / Б. Н. Чичерин. - М.: Типолитогр. т-ва «Кушнеров и Ко», 1900. С. 188.

${ }^{29}$ См.: Бошно С. В. Указ. соч. С. 82-91.

${ }^{30}$ См.: Иванов И. С. Указ. соч. С. 32-36.

${ }^{31}$ См. Савсерис С. В. Указ. соч. С. 13.
} 


\section{Политика и общество 8 (104) • 2013}

избежно ведут к унификации качеств нравственного самосознания человека, отрицанию каких-либо его индивидуально-личностных особенностей, а, главное, волевой составляющей и элементов духовной независимости, что невозможно в принципе, поскольку все это в конечном итоге нивелирует подлинное значение совести. Недаром еще в руссоистской концепции лишение человека свободы воли отождествлялось с лишением его действия какой бы то ни было нравственности. ${ }^{32}$ Б. Н. Чичерин же писал, что только действие по собственному побуждению может означать действие по совести, ибо последняя есть самое свободное из всего существующего в мире, и она не подчиняется никаким внешним понуждениям. ${ }^{33}$ В то же время, следует признать, что совесть, несмотря на имеющиеся сложности с ее терминологической идентификацией, выступает важнейшей движущей силой нравственного совершенствования субъекта и развития его свободы, прежде всего, внутренней. В этом видится одно из совпадений морали и права, способствующее формированию правомерного поведения в общественных отношениях, поскольку и правовые, и нравственные нормы базируются на принципах равенства, справедливости, недопустимости обмана и нетерпимости к произволу.

\section{Неправовые категории как средство делимитации свободы}

В основной своей массе мыслители считают категорию добра понятийно неопределимой, но признают, что она обладает способностью интуитивного постижения. При этом немецкий философ Н. Гартман утверждал, что добро может быть рационально понято как телеология ценностей - целенаправленное претворение в жизнь ценностей, а зло - как телеология антиценностей в реальном мире. ${ }^{34}$ Становится очевидной субъективность понятий добра, зла, совести и образованных на их основе категорий добросовестности и недобросовестности, которая противоречит принципам формальной определенности правовых предписаний, а такое противоречие, в свою очередь, не позво-

\footnotetext{
${ }^{32}$ См.: Руссо Ж. Ж. Об общественном договоре. Трактаты / Пер. с фр. А. Д. Хаютина, В. С. Алексеева-Попова. - М.: КАНОН-пресс, Кучково поле, 1998. С. 204.

${ }^{33}$ См.: Чичерин Б. Н. Указ. соч. С. 189.

${ }^{34}$ См.: Гартман Н. Этика / Пер. А. Б. Глаголева. - СПб: Владимир Даль, 2002. С. 374-375.
}

ляет гарантировать единство и равенство участников правоотношений в границах справедливо установленной свободы. Рецепция системой налогово-правового регулирования понятий абстрактного толка, чье содержание не позволяет однозначно определить неприемлемое поведение, четко уяснить границы дозволенного, вследствие чего возникает потребность их субъективной оценки, но уже на основании внеправовых представлений о сущем и должном, обрекает любое налогово-правовое предписание на утрату им собственно правовой составляющей. В отсутствие же последней не остается ничего, кроме соображений экономической целесообразности и претензий к морально-нравственному облику субъекта, априори сомнительных в силу их релятивистского характера. Благое желание создать общую норму, тем самым, вызывает необходимость перманентной коррекции процесса реализации принципа правовой свободы правоприменительной деятельностью, где преимущество вне всяких сомнений будет принадлежать властному субъекту, ведь именно ему как законодателю известен замысел конкретного налогового закона, скрытый для остальных в отсутствие четких формальных предписаний, а потому его же усмотрением этот замысел будет претворяться в жизнь.

В этой связи сегодня в сфере налоговых правоотношений как никогда актуальными стали убеждения С. А. Муромцева в необходимости предоставления судебной власти главенствующей роли во всей правоохранительной системе. «Суд должен превратиться в арбитра между законом и конкретным правоотношением, он будет в соответствии с господствующей справедливостью проверять степень современности, жизненности того или иного закона, то есть приводить стабильный и негибкий закон в соответствие с изменчивыми запросами жизни, с живым правопорядком, где источником правотворчества судей является справедливость». ${ }^{35}$ И, действительно, в настоящее время именно судебная власть несет на себе основную нагрузку, вызванную, с одной стороны, необходимостью устранения юридико-технических просчетов законодателя в налоговой сфере, a, с другой, вычленения из текста закона истинной воли законодателя и доведения ее до сведения сторон налогового спора, а также иных заинтересованных лиц.

\footnotetext{
${ }^{35}$ Муромиев С. А. Очерки общей теории гражданского права. Ч. 1 / С. А. Муромцев. - М.: Тип. А. И. Мамонтова и Ко,
} 1877. C. 223. 
При этом исследователями наблюдается тенденция перехода от буквального к телеологическому истолкованию налоговых норм. ${ }^{36}$ Однако опасность судейского усмотрения при том, что в разумных пределах оно может быть полезным для отступления от статического формализма, состоит в практически единомоментном формировании и применении критериев, являющихся основанием критического отношения к поведению субъекта. Предоставление правоприменителю возможности определять наличие в деятельности фискально-обязанных лиц признаков нарушения границ свободы, исходя из собственных аксиологических соображений, внутренне сложившихся убеждений в важности или индифферентности этической окраски экономико-правового бытия, вытесняет саму возможность усмотрения за пределы правовой формы существования и осуществления свободы.

Другой недостаток искусственно заимствованных налоговым правом извне категорий заключается в вариативности нравственных установок. В разное время оценки одних и тех же финансово-правовых явлений переживали многократные метаморфозы, в большинстве своем обусловленные популярностью конкретных субъективных взглядов и предлагаемых обществу идей. «Если бы мы имели время и возможность бросить взгляд на общую финансовую историю европейских стран, - говорил И. И. Янжул, - то увидели бы, какие разнообразные злоупотребления, какие нарушения выгод различных классов народов... могут быть следствием неумелой или ошибочной организации налогов». ${ }^{37}$ Так, в рамках одной только теории единого налога половина считала ее несправедливой как не уделяющей должного внимания принципам равномерности и всеобщности, а еще половина, наоборот, единственной обеспечивающей справедливость, прозрачность и понятность налогообложения. Аналогичным образом общество периодически задается вопросом о моральной допустимости переложения реального налогового бремени с одних лиц на других. М. И. Фридман отмечал, что «вопрос о том, несет ли налог его юридический плательщик, или последний может перенести податную тягость на других лиц, является необходимой предпосылкой для разрешения вопросов о на-

\footnotetext{
${ }^{36}$ См.: Евдокимов П. В. Указ. соч. С. 177.

37 Янжул И. И. Основные начала финансовой науки: Учение о государственных доходах / И. И. Янжул. - М.: Статут, 2002. C. 244.
}

логовой справедливости». ${ }^{38}$ При этом все тот же И. И. Янжул считал указанную дилемму теоретически неразрешимой. ${ }^{39}$ Помимо прочего, немаловажным фактором, оказывающим влияние на соотношение правовых и этических институтов, а также оценку степени востребованности последних в социуме, выступает текущая политическая, экономическая и гуманитарная обстановка и соответствующая ей государственная политика, суть или изменение которой могут по-разному толковаться властью и подвластными субъектами. Таким образом, не исключены и даже весьма вероятны явления налогово-правового бытия, абсолютно приемлемые с точки зрения нравственности для одних и крайне аморальные для других. Конечно же, ни о какой формальной свободе в подобных ситуациях говорить нельзя.

Свобода есть тогда, когда ее можно отграничить от произвола, при этом критерии такого отграничения должны быть гласными. Неотъемлемым элементом принципа правовой определенности свободы является предоставление каждому, тем более лицу, держащему ответ перед публичной властью, права быть поставленным в известность, какие требования к его поведению предъявляются и где находятся рамки, выход за пределы которого ограничен или запрещен. Обратное как следствие неписаного характера оценочных категорий неизбежно порождает негативный плюрализм в понимании их предметного содержания. В частности, первый же взгляд на понятие добросовестности дает возможность интерпретировать его двояко: как реализацию свободы в условиях неосведомленности о наличии ограничивающих эту свободу обстоятельств и как реализация свободы в условиях верификации наличия или отсутствия препятствующих ей обстоятельств. При этом оба варианта удовлетворения зова совести могут проистекать из чистых помыслов субъекта.

Сегодня же конкретные критерии добросовестности, разумности и осмотрительности вырабатываются в ходе практического применения терминов вкупе с близкими его правовой природе нормами. При этом не последнюю роль в оправдании того или иного подхода к раскрытию содержания названных категорий играет личность правоприменителя и его индивидуальное правосознание. Негативный эффект от использова-

\footnotetext{
${ }^{38}$ Пушкарева В. М. История финансовой мысли и политики налогов / В. М. Пушкарева. - М.: Финансы и статистика, 2008. C. 148.

${ }^{39}$ См.: Янжул И. И. Указ. соч. С. 276.
} 


\section{Политика и общество 8 (104) • 2013}

ния не известных праву морально-этических принципов еще более усугубляется, когда частный взгляд на касающуюся многих проблему возводится в ранг наставлений участникам правоотношений придерживаться определенного поведения, поскольку все иное не соответствует мнению правоприменителя, будь то чиновник или судья, о должных нравах в социуме. Тем самым, наблюдается банальное навязывание чужого образа мышления, тогда как еще И. В. Михайловский развел по сторонам регулятивные потенциалы права и нравственности, указав, что первое должно остерегаться предписывать, как и порицаемых, так и вменяемых вторым поступков. ${ }^{40}$ Подобный ход событий хорошо прослеживается в преемственности судебной практики, основанной на прецеденте как способе адаптации этических норм в правовой сфере.

Таким образом, одно из ключевых препятствий к использованию нравственных категорий в налоговом праве заключается в существовании социально-исторических и личностно-индивидуальных различий в понимании высшего блага, целей и путей его достижения. Выдающийся русский философ К. Н. Леонтьев отмечал: «Обыкновенный суд, точно так же как и справедливая полицейская расправа, суть проявление лишь «правды внешней», и ни государственный суд, ни суд так называемого общественного мнения, ни полицейская расправа не исчерпывают бесконечных прав личного духа, до глубины которого не всегда могут достигать общие правила законов и общие повальные мнения людей». ${ }^{41}$ Как следствие, идеи добра и зла получают самое различное содержание в зависимости от субъективных факторов, концентрируясь на том или ином внутренне имплицированном представлении о справедливости, отношении к правовой и экономической реальности. Неразрывная связь моральных установок с дифференцированным пониманием блага порождает совершенно ненужные налоговому праву релятивизм, а иногда и сознательный оппортунизм, которые начинают играть роль деструктивных элементов, снижающих эффективность и действенную силу системы правового регулирования, в конечном итоге, подвергающих сомнению вечные принципы верховенства закона и господства права.

Рассматривая проблему свободы в налоговом праве, не лишним будет оценить гносеологический потен-

\footnotetext{
${ }^{40}$ См.: Савсерис С. В. Указ. соч. С. 9.

${ }^{41}$ Леонтьев К. Н. Храм и церковь / Религиозно-философские произведения 1831-1891 гг. - М.: АСТ, 2003. С. 511.
}

циал собственно науки философии права в попытке осмысления неправовых понятий. Если известно, что любая мораль имеет своей целью установление универсальных, обращенных к идеям добра и справедливости правил общежития, то никакое волеизъявление не может быть оправдано реализацией исключительно частного интереса, не согласованного с общезначимым благом, оно априори аморально. Отсюда следует очевидный вывод, что использование возможностей предоставленной свободы допустимо до тех пор, пока это не препятствует осуществлению свободы других. Подобное моральное требование, как видится, обусловлено универсальным приложением идеи отрицания абсолютного характера свободы, ${ }^{42}$ а также тесным пересечением в обществе мер возможного и должного поведения множества субъектов с полярными интересами. В фискальной среде в качестве моральной предпосылки урегулирования конфликтов по доброй совести предлагается идея всеобщей включенности и заинтересованности в решении задач налогообложения, в рамках которой утрачивают свое былое значение различия в мотивации налогоплательщиков и казны. Многими считается, что непринятие или непонимание миссии свободы в налоговом праве, заложенной в данной идее, влечет игнорирование не только публичных, но и частных интересов. ${ }^{43}$ Подобное видение путей выхода из сложной ситуации восходят корнями к философии эпохи просвещения, где Ж. Ж. Руссо видел гарантии сохранения свободной природы членов человеческого социума в том, что каждый отдельный индивидуум вовлечен в формирование и осуществление общей воли, составляющей совокупность индивидуальных воль всех свободных и равноправных членов общества. ${ }^{44}$ Очевидно, что сопротивление общей воли, олицетворяемой государством, означает не разделение интересов с каждым из членов общества, а потому не укладывается в традиционные нравственные каноны. Казалось бы, все логично и даже духовно конструктивно. Однако избранные сегодня способы экстраполяции этических норм на явления налогово-правового бытия носят откровенно монистический, если

${ }^{42}$ См.: Осакве К. Экономико-философская интерпретация договора в англо-американском общем праве: либеральная теория договора // Журнал российского права. - 2004. - №9. C. 91-106.

${ }^{43}$ См.: Зарипов В. М. О соотношении экономики и права в налогах // Налоговый вестник. - 2005. - №2. С. 27-29.

${ }^{44}$ См.: Руссо Ж. Ж. Указ. соч. С. 210-212. 
не сказать - дискриминационный, характер. Основной их недостаток заключается в молчаливом согласии на применение оценочных понятий лишь к фискально-обязанным лицам, вследствие чего принцип формального равенства остается не у дел, без которого, как уже выяснилось, никакая свободы не возможна. В свою очередь, о необходимости распространения аналогичного понятийного аппарата, включая критерии доброй совести, коль скоро они используются в налоговых правоотношениях, на публично-правовые субъекты свидетельствуют соответствующие призывы юридического сообщества. ${ }^{45}$

\section{Злоупотребление свободой в налоговом праве}

Следует отметить, что все общефилософские категории, включая «добро», «зло», «совесть», «разумность», изначально имеющие позитивную нравственную окраску, но реципируемые правом в целях порицания вредоносного использования идеи свободы участниками правоотношений, по своей сути охватываются понятием «злоупотребление свободой». Сразу оговоримся, что указанное понятие, наравне с остальными, не известно финансово-правовой науке, и его применение в силу чуждой императивной природе публичного права диспозитивности вовсе не бесспорно, хотя среди специалистов все чаще звучат и противоположные мнения. ${ }^{46}$ Объединяющим признаком вышеназванной категории является волевой поведенческий аспект, а именно мотив и цель, детерминированные внутренним отношением лица к собственным потребностям и способам их удовлетворения. Можно сказать, что, обращаясь к внутренней свободе субъекта, нравственность возлагает на него негласную обязанность, прежде всего, пассивного поведения посредством воздержания от такого использования прав и свобод, которое претит самой нравственности, чем на деле сужает формальные рамки предоставленной правом свободы. При этом не следует забывать, что в контексте налоговых правоотношений, обязательные предписания, адресованные налогоплательщикам и иным участникам финансовых отношений в связи с мобилизацией финансовых ресурсов, не будучи облеченные в соответствующую правовую форму, спо-

${ }^{45}$ См.: Сасов К. А. Защита от недобросовестных действий должностных лиц налоговых органов // Налоговые споры: теория и практика. - 2008. - №7. С. 14-19.

${ }^{46}$ См. Запольский С. В. Указ. соч. С. 99. собны превращаться в «несанкционированный отбор» государством денежных средств у своих граждан, организаций и иных хозяйствующих субъектов. ${ }^{47}$

Внешняя сторона злоупотребления свободой проявляется в нарушении пределов дозволенного, но в форме, что очень важно, не сопряженной с нарушением ограничений и запретов. Сущность использования свободы во зло состоит в совершении действий (бездействия), формально допускаемых правом, но при этом направленных на соискание явно не правовых ценностей, в том числе на причинение вреда другим лицам. Не вызывает сомнения, что намерения, преследующие единственную цель причинения ущерба чьим бы то ни было интересам, включая интересы казны, выходят за рамки правовой формы реализуемой в этот момент свободы. В то же время не следует отождествлять вред с любой формой утраты или неполучения того или иного блага, пусть даже обусловленной конкретными действиями (бездействием) субъекта права. Вредоносными нельзя назвать последствия, которые с равной степенью закономерности возникли бы и при отсутствии злой воли, в результате совершения обычных и экономически оправданных объективными обстоятельствами хозяйственных операций. Идея порицания злоупотребления свободой теоретически применима как к налогоплательщикам, так и к государству, осуществляющему такого властное воздействие, которое соответствует формально закрепленным за тем или иным органом правомочиям, но явно выходит за пределы разумных интересов казны, претит им или опирается исключительно на фискальную функцию налогообложения, игнорируя все остальные. В подтверждение изложенного можно привести слова И. И. Янжула, утверждавшего, что, «с одной стороны, предел обложения лежит в размерах потребностей государства, для покрытия которых налоги устанавливаются, с другой - он заключается в имущественной способности подданных удовлетворять этим потребностям». ${ }^{48}$ При этом необходимо исключить всякую вероятность добросовестного заблуждения властного субъекта в представлениях о собственных границах свободы, поскольку его знание априорно, оно презюмируется инициативной ролью государства в регуляции общественных отношений.

Злоупотребление свободой может выражаться и в искажении ее предназначения, то есть цели, достиже-

\footnotetext{
${ }^{47}$ См.: Козырин А. Н. Указ. соч. С. 7.

48 Янжул И. И. Указ. соч. С. 245.
} 


\section{Политика и общество 8 (104) • 2013}

нию которой обычно служит определенная совокупность возможностей. При этом познание предназначения свободы в налоговых правоотношениях может осуществляться как на основе формализованных правовых предписаний, так и исходя из существа конкретного дозволения. Сегодня проблемы, связанные с исследованием цели, которую лицо ставило перед собой, привлекают все большее внимание финансово-правовой науки, ${ }^{49}$ что обусловлено широким распространением фактов злоупотребления в налоговой практике. В ситуации принудительной коррекции вектора движения свободы участник правоотношений для достижения желаемой цели, но при отсутствии намерения к реализации задач, традиционно свойственных этой цели, искусственно создает видимость благой воли, оставаясь связанным лишь собственными потребностями и, тем самым, нанося ущерб подлинным идеалам реалистичности, непосредственности и доброй воли. Подобные поступки характеризуются пороком воли субъекта, а блага, обретенные в результате подмены смысла свободы, не имеют психически опосредованного отражения в объективной реальности и не привносят в нее новые проявления нравственности.

Несмотря на то, что философия права в целом считает недопустимым введение в правовое поле морально-этических категорий, необходимо признать основополагающую и даже фундаментальную значимость понятия добра, а равно проистекающих из него и традиционно возводимых в ранг общих принципов права требований разумности, добросовестности и справедливости, в социальном бытии и, в том числе, его налогово-правовом воплощении. Однако нарушение моральных норм не должно выступать основанием возникновения неблагоприятных правовых и связанных с ними экономических последствий для участников налоговых правоотношений. Формальное предписание, лишенное ясной каждому объективной интенции, нивелирует свою правоохранительную функцию, поскольку допускает произвольное толкование в зависимости от таких нюансов, которые не могут быть предварительно приняты в расчет для организации и дальнейшего осуществления какого-либо замысла. Таким образом, «если предположить, что норма права может иметь в своей структуре ссылку на нравственную норму, то такая норма права, - как отмечает С. В. Савсерис, - перестает ею быть, она разрушается. Такая норма теряет свою определенность,

${ }^{49}$ См.: Евдокимов П. В. Указ. соч. С. 177. не обеспечивая применителей информацией о ее границах... А значит, какое-либо действие субъекта могло бы оцениваться одними как соответствующее этой норме, другими - как несоответствующее». ${ }^{50}$ В свою очередь, А. Н. Козырин, ожидая еще более глобальные последствия описанной проблемы, пишет, что «от возможности нахождения «результирующего» вектора... будет зависеть в конечном итоге социально-экономическая и политическая стабильность в государстве, возможность нормального функционирования всех без исключения общественных и государственных институтов». ${ }^{51}$ Можно предположить, что в лице подобных последствий, пагубных для стабильности налоговой системы в целом, не исключается деформация уже сложившихся в единстве со всей правовой наукой постулатов в стремлении решить частные вопросы правоприменения, прибегая к обобщенным моральным канонам в ущерб предметной работе по совершенствованию юридической техники. Ведь этические нормы по большей части синкретичны и содержат рекомендации универсального характера, что называется «на все случаи жизни», тогда как в реальности нередко требуются различные подходы к регулированию отдельного рода общественных отношений, с чем право способно справиться более успешно.

Единственный смысл нравственных наставлений заключается в способности ориентировать фискальнообязанных и уполномоченных лиц на необходимость уважения в своей деятельности общепринятых требований морали. В противном случае возрастает риск возникновения деспотических режимных элементов, при которых синкретичность правовых и нравственных норм позволяет государственному механизму повсеместно осуществлять карающее воздействие в отношении подвластных субъектов за их несоответствие неким вариативным критериям, называемым нравственными. В то же время, налоговое право в соответствии со своей правоохранительной функцией призвано оградить как государство, так и объединенных им членов общества от экономически вредоносных явлений. Однако цели защиты от противоправных посягательств на законные интересы, прежде всего, достигаются путем установления правовых запретов и ограничений, но никак не воплощения в жизнь основанной на принципах субъективного усмотрения системы оценки действий (бездействия) на предмет их соразмерности абстрактным и

\footnotetext{
${ }^{50}$ Савсерис С. В. Указ. соч. С. 12.

${ }^{51}$ Козырин А. Н. Указ. соч. С. 8.
} 
релятивистским представлениям о столь же субъективном идеале должного поведения. При этом вне зависимости от приведенных аргументов против интеграции общефилософских и иных неправовых понятий в налогово-правовую сферу, можно с уверенностью сказать, что наполняющие их содержание морально-нравственные идеи, будучи воспринятыми в качестве руководящего начала процесса правотворчества, способны сослужить добрую службу развитию принципа свободы в фискальных отношениях.

\section{Библиография:}

1. Винницкий Д. В. Субъекты налогового права / Д. В. Винницкий. - М.: Норма, 2000. - 192 с.

2. Гартман Н. Этика / Пер. с нем. А. Б. Глаголева. СПб: Владимир Даль, 2002. - 707 с.

3. Гегель Г. В. Ф. Лекции по философии и истории / Пер. А. М. Водена. - СПб: Наука, 2000. - 480 с.

4. Гегель Г. В. Ф. Философия права / Пер. с нем. Б. Г. Столпнера, М. И. Левиной. - М.: Мысль, 1990. - 524 c.

5. Запольский С. В. Дискуссионные вопросы теории финансового права: монография / С. В. Запольский. - М.: Эксмо, 2008. - 160 с.

6. Левицкий С. А. Свобода и ответственность: «основы органического мировоззрения» и статьи о солидаризме / Сост. и коммент. В. В. Сапова. М.: Посев, 2003. - 464 с.

7. Леонтьев К. Н. Храм и церковь / Религиозно-философские произведения 1831-1891 гг.-М.: АСТ, 2003. - 640 c.

8. Микешина Л. А. Философия науки. Эпистемология. Методология. Культура / Л. А. Микешина. М.: Издательский дом Международного университета в Москве, 2006. - 764 с.

9. Монтескье Ш. Л. Избранные произведения / Пер. А. Г. Горнфельда, М. М. Ковалевского. - М.: Госполитиздат, 1955. - 800 с.

10. Муромцев С. А. Очерки общей теории гражданского права. Ч. 1 / С. А. Муромцев. - М.: Тип. А. И. Мамонтова и Ко, 1877. - 317 с.

11. Нерсесянц В. С. Право - математика свободы. Опыт прошлого и перспективы / В. С. Нерсесянц. - М.: Юристъ, 1996. - 160 с.

12. Пушкарева В. М. История финансовой мысли и политики налогов / В. М. Пушкарева. - М.: Финансы и статистика, 2008. - 256 с.
13. Россия глазами русского: Чаадаев, Леонтьев, Соловьев / Сборник РАН. Сост. А. Ф. Замалеев. СПб. Наука, 1991. - 363 с.

14. Руссо Ж. Ж. Об общественном договоре. Трактаты / Пер. с фр. А. Д. Хаютина, В. С. Алексеева-Попова. - М.: КАНОН-пресс, Кучково поле, 1998. - 416 с.

15. Савсерис С. В. Категория «недобросовестность» в налоговом праве / С. В. Савсерис. - М.: Статут, 2007. - $191 \mathrm{c}$.

16. Финансовое право России: актуальные проблемы / Под ред. А. А. Ялбулганова. - М.: Academia, 2007. - 288 c.

17. Чичерин Б. Н. Философия права / Б. Н. Чичерин. - М.: Типолитогр. т-ва «Кушнеров и Ко», 1900. $337 \mathrm{c}$.

18. Янжул И. И. Основные начала финансовой науки: Учение о государственных доходах / И. И. Янжул. - М.: Статут, 2002. - 555 c.

19. Сасов К. А. Защита от недобросовестных действий должностных лиц налоговых органов // Налоговые споры: теория и практика. - 2008. - №7. - С. 14-19.

20. Иванов И. С. О влиянии социально-философских и психологических учений на восприятие вины у налогоплательщиков // Российский следователь. 2008. - №2. - С. 32-36.

21. Орлова О. В. Правовая свобода личности в гражданском обществе // Журнал российского права. 2007. - №5. С. 76-83.

22. Кузубова А. Ю. Тема прав и свобод человека в философской концепции К. Н. Леонтьева / А. Ю. Кузубова, Е. В. Сафронова // История государства и права. - 2006. - №12. - С. 33-35.

23. Чернобель Г. Т. Право как мера социального блага // Журнал российского права. - 2006. - №6. С. 83-95.

24. Зарипов В. М. О соотношении экономики и права в налогах // Налоговый вестник. - 2005. - №2. - С. 27-29.

25. Осакве К. Экономико-философская интерпретация договора в англо-американском общем праве: либеральная теория договора // Журнал российского права. - 2004. - №9. - С. 91-106.

26. Суханов Е. А. Осторожно: гражданско-правовые конструкции // Законодательство. - 2003. - №9. - C. 60-65.

27. Бошно С. В. Доктринальные и другие нетрадиционные формы права // Журнал российского права. - 2003. - №1. - C. 82-91. 


\section{Политика и общество 8 (104) • 2013}

28. Черненко А. К. Взаимодействие права и свободы: проблемы интеграции // Гуманитарные науки в Сибири. - 2000. - №1. С. 85-91.

29. Назаретян А. П. Совесть в пространстве культурно-исторического бытия (полемические заметки) // Общественные науки и современность. - 1994. - №5. C. 152-160.

30. Фарбер И. Е. О классово-волевом характере права // Правоведение. - 1957. - №1. - С. 3241.

31. Михайлов П. В. «Положительная» и «отрицательная» свобода в русской религиозной философии начала XX века // София: рукописный журнал Общества ревнителей русской философии. - 2001. - №3. URL: http://www.rustrana.ru/print. php?nid=13181.

\section{References (transliteration):}

1. Vinnickiy D. V. Sub'ekty nalogovogo prava / D. V. Vinnickiy. - M.: Norma, 2000. - 192 c.

2. Gartman N. Etika / Per. s nem. A. B. Glagoleva. SPb: Vladimir Dal', 2002. - 707 s.

3. Gegel' G. V. F. Lekcii po filosofii i istorii / Per. A. M. Vodena. - SPb: Nauka, 2000. - 480 s.

4. Gegel' G. V. F. Filosofiya prava/ Per. s nem. B. G. Stolpnera, M. I. Levinoy. - M.: Mysl', 1990. -524 s.

5. Zapol'skiy S. V. Diskussionnye voprosy teorii finansovogo prava: monografiya / S. V. Zapol'skiy. M.: Eksmo, 2008. - 160 c.

6. Levickiy S. A. Svoboda i otvetstvennost': «osnovy organicheskogo mirovozzreniya» i stat'i o solidarizme / Sost. i komment. V. V. Sapova. - M.: Posev, 2003. - $464 \mathrm{~s}$.

7. Leont'ev K. N. Hram i cerkov' / Religiozno-filosofskie proizvedeniya 1831-1891 gg. - M.: AST, 2003. $-640 \mathrm{~s}$.

8. Mikeshina L. A. Filosofiya nauki. Epistemologiya. Metodologiya. Kul'tura / L. A. Mikeshina. - M.: Izdatel'skiy dom Mezhdunarodnogo universiteta $\mathrm{v}$ Moskve, 2006. - 764 s.

9. Montesk'e Sh. L. Izbrannye proizvedeniya / Per. A. G. Gornfel'da, M. M. Kovalevskogo. - M.: Gospolitizdat, 1955. - 800 c.

10. Muromcev S. A. Ocherki obschey teorii grazhdanskogo prava. Ch. 1 / S. A. Muromcev. - M.: Tip. A. I. Mamontova i Ko, 1877. - 317 s.
11. Nersesyanc V. S. Pravo - matematika svobody. Opyt proshlogo i perspektivy / V. S. Nersesyanc. - M.: Yurist', 1996. - 160 s.

12. Pushkareva V. M. Istoriya finansovoy mysli i politiki nalogov / V. M. Pushkareva. - M.: Finansy i statistika, 2008. - $256 \mathrm{~s}$.

13. Russo Zh. Zh. Ob obschestvennom dogovore. Traktaty / Per. s fr. A. D. Hayutina, V. S. Alekseeva-Popova. - M.: KANON-press, Kuchkovo pole, 1998. - 416 s.

14. Savseris S. V. Kategoriya «nedobrosovestnost'» V nalogovom prave / S. V. Savseris. - M.: Statut, 2007. $-191 \mathrm{~s}$.

15. Chicherin B. N. Filosofiya prava / B. N. Chicherin. M.: Tipolitogr. t-va «Kushnerov i Ko», 1900. - 337 s.

16. Yanzhul I. I. Osnovnye nachala finansovoy nauki: Uchenie o gosudarstvennyh dohodah / I. I. Yanzhul. - M.: Statut, 2002. - 555 s.

17. Sasov K. A. Zaschita ot nedobrosovestnyh deystviy dolzhnostnyh lic nalogovyh organov // Nalogovye spory: teoriya i praktika. - 2008. - №7. - S. 14-19.

18. Ivanov I. S. O vliyanii social'no-filosofskih i psihologicheskih ucheniy na vospriyatie viny $u$ nalogoplatel'schikov // Rossiyskiy sledovatel'. 2008. - №2. - S. 32-36.

19. Orlova O. V. Pravovaya svoboda lichnosti v grazhdanskom obschestve // Zhurnal rossiyskogo prava. 2007. - №5. S. 76-83.

20. Kuzubova A. Yu. Tema prav i svobod cheloveka v filosofskoy koncepcii K. N. Leont'eva / A. Yu. Kuzubova, E. V. Safronova // Istoriya gosudarstva i prava. - 2006. - №12. - S. 33-35.

21. Chernobel' G. T. Pravo kak mera social'nogo blaga // Zhurnal rossiyskogo prava. - 2006. - №6. S. 83-95.

22. Zaripov V. M. O sootnoshenii ekonomiki i prava v nalogah // Nalogovyy vestnik. - 2005. - №2. - S. 2729.

23. Osakve K. Ekonomiko-filosofskaya interpretaciya dogovora $\mathrm{v}$ anglo-amerikanskom obschem prave: liberal'naya teoriya dogovora // Zhurnal rossiyskogo prava. - 2004. - №9. - S. 91-106.

24. Suhanov E. A. Ostorozhno: grazhdansko-pravovye konstrukcii // Zakonodatel'stvo. - 2003. - №9. S. 60-65.

25. Boshno S. V. Doktrinal'nye i drugie netradicionnye formy prava // Zhurnal rossiyskogo prava. - 2003. №1. - S. 82-91.

26. Chernenko A. K. Vzaimodeystvie prava i svobody: problemy integracii // Gumanitarnye nauki v Sibiri. 2000. - №1. S. 85-91. 
27. Nazaretyan A. P. Sovest' v prostranstve kul'turno-istoricheskogo bytiya (polemicheskie zametki) // Obschestvennye nauki i sovremennost'. - 1994. - №5. S. 152-160.

28. Farber I. E. O klassovo-volevom haraktere prava // Pravovedenie. - 1957. - №1. - S. 32-41.
29. Mihaylov P. V. «Polozhitel'naya» i «otricatel'naya» svoboda $\mathrm{V}$ russkoy religioznoy filosofii nachala XX veka // Sofiya: rukopisnyy zhurnal Obschestva revniteley russkoy filosofii. - 2001. - №3. URL: http://www.rustrana.ru/print.php?nid=13181. 